\title{
The Impacts of Government Policy on Covid-19 to Airlines Liability: A Case Study in Indonesia
}

\author{
Elfrida Ratnawati ${ }^{1}$
}

1Faculty of Law, Universitas Trisakti Jakarta, Indonesia. Email: elfrida.r@trisakti.ac.id

\begin{tabular}{l} 
Article Info \\
\hline Kata Kunci : \\
Aviation law; Force \\
majeure; Airline \\
industry; covid-19. \\
How to cite (APA \\
Citation Style): \\
Ratnawati, E. \\
(2021). "The \\
Impacts of \\
Government Policy \\
on Covid-19 to \\
Airlines Liability: A \\
Case Study In \\
Indonesia”. Jambura \\
Law Review. \\
JALREV 3 (1): 72-92 \\
\hline
\end{tabular}

\section{Article Info}

Kata Kunci : majeure; Airline industry; covid-19.

How to cite $(A P A$

Impacts of

Government Policy

on Covid-19 to

Case Study In

Indonesia". Jambura

Law Review.

Under the license CC BY-SA 4.0

\begin{abstract}
The impact of Covid-19's impact on the air transportation sector, especially in Indonesia. This article will discuss the impact and responsibility of airlines on the policies adopted by the Indonesian government regarding the COVID-19 pandemic. This article uses a normative juridical legal approach, research based on literature or secondary material. Meanwhile, the data obtained through legal analysis and social phenomena that occur in society. The rules that must be obeyed by airlines require them to do flight restrictions and cancellations. As a consequence of the cancellation, the airline must return the funds to passengers who have purchased travel tickets and the airline cannot hide behind force majeure. As the party issuing policies, the Government must be able to see a balance in social life and provide appropriate legal protection. In addition, the Government may not issue policies that can lead to different interpretations of those who read the policies. These strict regulations are needed so that passenger rights can be realized which is the responsibility of the airline.
\end{abstract}

\section{Introduction}

There is a close relationship between the transportation sector and a country's economy, where the growth of the transportation sector certainly reflects a country's economic growth directly. Therefore, the transportation sector has an important and strategic role, both macro and micro, in the economic growth of a nation. In this case, 
the air transportation sector plays the most important role ${ }^{1}$. There is an interrelated relationship between air transportation and economic development, it is possible to have a connection from time to time ${ }^{2}$. The growth of air transportation plays an important role in the global economy ${ }^{3}$. Based on the data, in 2004, there was as many as $40 \%$ of international tourists travelling using air transportation, and $40 \%$ transportation of goods or logistcs contributed in both interational and regional export ${ }^{4}$.

Air transport is vital for international trade in manufactured goods, particularly for the components industry that accounts for a major part of cross border trade today. We forecast that the value of international trade shipped by air this year will be $\$ 5.8$ trillion, 10\% lower compared to 2019. However, it will above 2019 levels in 2021. Tourists travelling by air in 2020 are forecast to spend $\$ 347$ billion, $59 \%$ less than the previous year. Next year, tourists travelling by air are forecast to spend $\$ 559$ billion, equivalent to the level last seen in 2012. Another adverse impact of the crisis will be on jobs. Total employment supported (directly and indirectly) by the air transport sector is expected to decline to 42.8 million in 2020; a 51\% reduction relative to 2019 .

Table.1

\begin{tabular}{llll}
\hline Worldwide Airline Industry & 2019 & $2020 \mathrm{~F}$ & $2021 \mathrm{~F}$ \\
\hline Africa & & & \\
\hline Net post -tax profit,\$ billion & -0.3 & -2.0 & -1.7
\end{tabular}

${ }^{1}$ Siahaan, D. (February 21, 2018). "Pertumbuhan Sektor Transportasi Udara Mencerminkan Pertumbuhan Ekonomi Nasional". Retrieved from Suara Merdeka Https://www.haloindonesia.co.id

2 Tusmar, T., \& Mora, M. (2015). "Perkembangan Perekonomian Wilayah dan Kargo Wilayah dan Kargo Udara: Korelasi atau Kausalitas?". Warta Ardhia Jurnal Perhubungan Udara.

3 Nugraha, B. (2018, 2 20). "Pertumbuhan Sektor Transportasi Udara Cerminkan Ekonomi Nasional". Retrieved from Suara Merdeka: Https://www.suaramerdeka.com

${ }^{4}$ Button, K. (2011). “The Economist's Perspective on Regional Endogenous Development”. Cheltenham: Regional Endogenous Development. 


\begin{tabular}{|c|c|c|c|}
\hline Per passenger, $\$$ & -2.67 & -41.63 & -28.07 \\
\hline$\%$ revenue & $-1.8 \%$ & $-39.1 \%$ & $-27.6 \%$ \\
\hline RPK growth, \% & $4.7 \%$ & $-72.0 \%$ & $35.0 \%$ \\
\hline ASK growth,\% & $4.5 \%$ & $-62.8 \%$ & $21.5 \%$ \\
\hline Load factor, \% ATK & $55.4 \%$ & $48.8 \%$ & $49.0 \%$ \\
\hline Breakeven load factor, \% ATK & $54.9 \%$ & $66.9 \%$ & $58.5 \%$ \\
\hline \multicolumn{4}{|l|}{ Asia Fasifik } \\
\hline Net post-tax profit, \$billion & 4.9 & -31.7 & -7.5 \\
\hline Per passenger, $\$$ & 2.90 & -36.40 & -6.30 \\
\hline$\%$ revenue & $1.9 \%$ & $-30.2 \%$ & $-5,3 \%$ \\
\hline RPK growth, \% & $4.7 \%$ & $-62.0 \%$ & $50.0 \%$ \\
\hline ASK growth,\% & $4.4 \%$ & $-55.1 \%$ & $38.4 \%$ \\
\hline Load factor, \% ATK & $72.5 \%$ & $65.8 \%$ & $67.5 \%$ \\
\hline Breakeven load factor, \% ATK & $69.1 \%$ & $77.6 \%$ & $69.9 \%$ \\
\hline \multicolumn{4}{|l|}{ Middle East } \\
\hline Net post-tax profit, \$billion & -1.5 & -7.1 & -3.3 \\
\hline Per passenger, $\$$ & -6.75 & -68.47 & -25.56 \\
\hline$\%$ revenue & $-2.7 \%$ & $-30.0 \%$ & $-10.8 \%$ \\
\hline RPK growth, \% & $2.3 \%$ & $-73.0 \%$ & $43.0 \%$ \\
\hline ASK growth,\% & $0.1 \%$ & $-64.5 \%$ & $23.6 \%$ \\
\hline Load factor, \% ATK & $65.0 \%$ & $54.4 \%$ & $56.4 \%$ \\
\hline Breakeven load factor, \% ATK & $68.4 \%$ & $73.0 \%$ & $64.2 \%$ \\
\hline \multicolumn{4}{|l|}{ Latin America } \\
\hline Net post-tax profit, \$billion & -0.7 & -5.0 & -3.3 \\
\hline Per passenger, $\$$ & -2.23 & -39.38 & -20.11 \\
\hline
\end{tabular}


$\%$ revenue

$-1.8 \% \quad-37.1 \% \quad-18.4 \%$

RPK growth, \%

$4.2 \% \quad-64.0 \% \quad 39.0 \%$

ASK growth, $\%$

$3.0 \% \quad-60.0 \% \quad 34.3 \%$

Load factor, \% ATK

$67.9 \% \quad 62.1 \% \quad 62.5 \%$

Breakeven load factor, \% ATK

$65.9 \% \quad 78.2 \% \quad 70.5 \%$

\begin{tabular}{llll} 
North America & & & \\
\hline Net post-tax profit, \$billion & 17.4 & -45.8 & -11.0 \\
Per passenger, \$ & 16.95 & -86.37 & -14.99 \\
\% revenue & $6.6 \%$ & $-41.4 \%$ & $-6.8 \%$ \\
RPK growth, \% & $4.0 \%$ & $-66.0 \%$ & $60.5 \%$ \\
ASK growth,\% & $2.9 \%$ & $-51.6 \%$ & $36.4 \%$ \\
Load factor, \% ATK & $65.6 \%$ & $52.8 \%$ & $55.0 \%$ \\
Breakeven load factor, \% ATK & $59.3 \%$ & $73.6 \%$ & $58.1 \%$
\end{tabular}

\begin{tabular}{llll}
\hline Europe & & & \\
\hline Net post-tax profit, \$billion & 6.5 & -26.9 & -11.9 \\
Per passenger, \$ & 5.42 & -51.25 & -16.66 \\
\% revenue & $3.1 \%$ & $-38.6 \%$ & $-12.0 \%$ \\
RPK growth, \% & $4.2 \%$ & $-70.0 \%$ & $47.5 \%$ \\
ASK growth, \% & $3.5 \%$ & -62.4 & $35.5 \%$ \\
Load factor, \% ATK & $73.0 \%$ & $63.8 \%$ & $65.6 \%$ \\
Breakeven load factor, \% ATK & $69.5 \%$ & $88.0 \%$ & $71.9 \%$
\end{tabular}

Note: RPK = Revenue Passenger Kilometers, ASK = Available Seat Kilometers, ATK = Available Tonne Kilometers. Current year or forward-looking industry financial assessments should not be taken as reflecting the performance of individual airlines, which can differ significantly. Sources: ICAO, IATA. ${ }^{5}$

5Ibid 
Table explanation that Airlines in North America, the strongest performer in the precrisis period, are estimated to post a net loss of $\$ 45.8 \mathrm{bn}$ in 2020. Nevertheless, in 2021 the recovery in North America is expected to be prompt compared to other regions. Net profit margin will improve to $-6.8 \%$ from $-41.4 \%$ in 2020 . The presence of large domestic markets will drive the improvement. The recovery in Europe will be more gradual due to a slower economic recovery and the importance of international services. Net losses are estimated to be $\$ 26.9$ billion for the region in 2020 as intraregional travel in Europe stalled as the second wave led to renewed travel restrictions. In 2021 , net losses are forecast to be $\$ 11.9$ billion, which corresponds to $12 \%$ of forecast revenues. Asia-Pacific was the first region exposed to the COVID-19 outbreak and the recovery started earlier in this region. AsiaPacific is expected to benefit from the recovery in large domestic markets such as China and India and also the strong economic rebound in China. China domestic market has already recovered to pre-crisis levels in 2020. Although airlines are lowering fares to stimulate demand, they are expected to cash breakeven by the year-end in China. In addition, the Asia Pacific region as a manufacturing hub benefits from the strength of cargo revenues Overall, net losses in 2021 are forecast to decline to $\$ 7.5$ billion, almost one fourth of the losses in 2020 . Middle Eastern airlines faced this crisis while a number of them were transitioning through a restructuring process which included a planned slowdown in capacity growth. Following the impact of the pandemic, Middle Eastern airlines are expected to see their losses rise to $\$ 7.1$ billion in 2020. Dependence of airlines in this region on connecting international flights and lack of large domestic markets will delay the recovery in the region. The net loss margin will be at double digit levels $(-10.8 \%)$ in 2021. In Latin America, airline performance was mixed prior to the crisis, with some airlines facing an already difficult economic and operating backdrop which has been compounded by the COVID-19 impact. Improvement in 2021 is expected to be slow and the region is forecast to post a $\$ 3.3$ billion net loss in 20216 .

The transportation policy in Indonesia closes every entry and exit spaces at airports and harbours, based on the Minister of Transportation Regulation No. 18 of 2020

${ }^{6}$ Ibid 
concerning Transportation Control in the Context of Preventing the Spread of Coronavirus Disease 2019 (COVID-19). This implementation affected the activities of airline companies. However, they must support the government's instruction related to the passenger safety and health policies in taking preventive measures to the spread of Coronavirus.

To suppress the spread of COVID-19 at the airports, various attempts were made by the Government both at the central and regional levels. These efforts are to optimize various adjustment activities in the field of airport operations, which began on April 1, 2020. All efforts were carried out in accordance with Government's instruction related to physical distancing policy, which was realized in the form of Circular Letter of Director of Aviation Security Number SE.10 of 2020 March 23, 2020 about the Prevention of COVID-19 Spread in Aviation. Matters relating to the operation of the airport are the management effort in carrying out airport operational efficiency amid a sharp decline in passenger traffic, which is around 25\% in March 2020 when compared to March 2019. The aim is to make efficiency efforts to reduce the operational time of most airports and public utilities ${ }^{7}$.

\section{Problem Statement}

Many cancellations occur both by the passenger and the airline. If the cancellation comes from the passenger, there is a mechanism through the management of the airline. But what if the flight is canceled by the airline, partly because the number of passengers does not meet the quota to fly, even though it has followed the social distancing rules set by the government.

\footnotetext{
7 PT Angkasa Pura. (March 20, 2020). "Sikapi Dampak Pandemi Covid 19, Angkasa Pura Airports Berlakukan Penyesuaian Operasional 15 Bandara”. Retrieved from PT. Angkasa Pura: https://ap1.co.id/id/information/news/detail/sikapi-dampak-pandemi-covid19-angkasa-puraairports-berlakukan-penyesuaian-operasional-15-bandara . Accessed April 20, 2020.
} 
The impact of Covid 19 has an effect on the air transportation sector, especially in Indonesia. This article will discuss the impact and responsibility of airlines on policies adopted by the Indonesia's government regarding the COVID-19 pandemic.

\section{Method}

This article uses a normative juridical legal approach, the research based on literature or secondary material. The regulations are used by the author to analyze the responsibilities of the airline in terms of losses to the air transport companies, related to the government's policy regarding restrictions on air transportation services due to Covid-19, in systematic, factual, and accurate research. This study uses a qualitative method with a descriptive analysis approach. Data are obtained through analysis of laws and social phenomena that occur in society. Firthermore, field fact testing is carried out as the basis for law theory and policy taken by the government as applicable guidelines or das sollen.

\section{Discussion}

\subsection{Facts about the Condtion of Aviation Sector in the World and Indonesia}

CNN Indonesia News on March 23, 2020 launched a list of countries that impose travel bans due to the Coronavirus. These countries are of the European Union that will limit non-emergency trips to the European Union for 30 days. Family members of European citizens, important staff such as doctors and nurses, and people who transport goods to the European Union are excluded from this regulation. The United States suspended travel from the United Kingdom and Ireland, two additional countries included in the enactment of the ban in addition to the 26 other countries on the list, except for American citizens or family members. Likewise, on March 18, 2020, the Australian Government issued a level 4 travel ban which meant prohibiting travel. Citizens who were traveling could still go home but had to be isolated for 14 days. Austria introduced border checks and banned all arrivals from Italy, Hubei Province, China, Iran and South Korea, with the exception of those who have health certificates for no more than four days which confirm that they are not affected by the Coronavirus. There are many more flight bans from various countries. All aim to ensure that no new cases of Covid-19 
enter their country ${ }^{8}$

Aviation activities in Indonesia, too, both domestically and internationally, felt a great impact caused by the Covid-19 outbreak. Many attempts were made by the Indonesian aviation sector to prevent the risk of transmitting Coronavirus and to increase the Government's efforts to suppres the spread of outbreaks. The operators of aviation transportation services have done various ways to survive when the Coronavirus continues to spread throughout the world and even many regions in Indonesia. Due to the rapid spread of the virus through transmission of inanimate objects and its resistence in the media, the efforts were done in various ways, from reducing departures to temporarily terminating services. People who have weak immune systems are very vulnerable to the risk of death, especially since the vaccine has not been found. Therefore, the government of Indonesia and countries in the world immediately take policies that have legal implications to have a detterent effect on people who violate these policies ${ }^{9}$. Many attempts were made by airlines to prevent bankruptcy, including closing down operations, laying off the employees such as pilots, cabin crew, technicians, and other supporting employees. Clearly, the Covid-19 pandemic has paralyzed almost all economic activity. The national aviation industry is badly affected, and its impact is not only felt by the aviation industry, but also its supporting industries, from aircraft repair shops, ground handling, and travel agents involved ${ }^{10}$.

The reduction in flight activities followed the order from Ministry of Transportation of the Director General of Civil Aviation, some time ago, considering that the airport was

${ }^{8}$ CNN Indonesia. (March 18, 2020). "Informasi Pembatalan Penerbangan Terkait Virus Corona, Accessed at 20 April 2020". Retrieved From CNN Indonesia: Https://www.m.cnnindonesia.com

9 Kata Data. (2020). "Cegah Corona Air Asia Setop Semua Penerbangan di Indonesia per 1 April 2020. Retrieved From Http://katadata.co.id . Accessed April 21, 2020

10 Widianto, S. (March 26, 2020). "Pandemi Covid-19, Industri Penerbangan Indonesia Terpuruk, Gelombang PHK Menghantui". Retrieved From Pikiran Rakyat Com: Http://www.pikiranrakyat.com . Accessed April 20, 2020 
one of the vital facilities and fast transportation facilities for the delivery of goods in the form of food and medical equipment. Nevertheless, the flight crew must be extra careful in serving passengers and need to require a body temperature check for all passengers, both those who will depart and those who have arrived at the destination airport. The body temperature check for all passengers and crew is a collaboration with the hospital by involving doctors and nurses. Those who have symptoms resembling Covid-19 will be directed to the hospital by health workers. Likewise, those whose body temperature is above 38 degrees. Several attempts were made, such as preparing hand sanitizers in public areas like departure and arrival rooms, and implementing social distancing in public areas. Other efforts include spraying disinfectants to all airport facilities, measuring the body temperature of all passengers and employees, and establishing a Covid-19 integrated task force post in collaboration with the health medical team ${ }^{11}$.

\subsection{Regulations by the Government of Indonesia}

One of the policies issued was Regulation of the Minister of Transportation of the Republic of Indonesia, Ministerial Regulation Number 18 of 2020 concerning “Transportation Control to Prevent the Spread of Coronavirus Disease 2019 (Ccovid19)". The ministerial regulation related to transportation restrictions in order to break the chain of virus transmission shows the commitment and seriousness of the Indonesian central government to protect and fulfill the right to health. The contents of the above regulations are as follows: "Article 1 states that the Control of Transportation to Prevent the Spread of Coronavirus Disease 2019 (COVID-19) is the form of restrictions on transportation modes"; "Article 2 states that Transportation to Prevent the Spread of Coronavirus Disease 2019 (COVID-19) is carried out through: controlling transportation for the entire region; transportation control in areas designated as LargeScale Social Restrictions; and transportation control for Eid homecoming activities in

11 Chaeruddin. (March 27, 2020). "Bandara Bua Kurangi Jadwal Penerbangan untuk Cegah Covid-19”. Retrieved From Sindo News: http://www.sindonews.com . Accessed April 20, 2020. 
2020"; "Article 9 states that transportation control in areas designated as Large-Scale Social Restrictions as referred to in Article 2 letter $b$ are for those that transport passengers and logistics/ goods", and "Article 14 is about the airport slot capacity reduction based on evaluation. This article regulates limiting the number of passengers to a maximum of 50 percent of the total seating capacity by applying physical distancing". This article also mentions adjustments to upper limit rates and / or enactments of surcharges based on statutory provisions. Since early March 2020, the passenger load factor (LF) of each aircraft of national airlines is no more than 50 percent. For example, on 10-11 April 2020, the load factor at Soekarno-Hatta Airport was less than 50 percent.

Government in many countries provide policies on their respective airlines in order to protect their citizens from the risk of virus transmission, considering that the potential spreads of the virus is through air transportation access, which is closely related to the entry and exit of international passengers. With the decreasing number of prospective passengers, airlines take the advantage of this pandemic to carry out aircraft engine maintenance. Simultaneously, many airplanes entered the maintenance period, especially for engine repairment and aircraft safety issues to remain guaranteed ${ }^{12}$.

\subsection{Airlines Responsibility for Passengers due to Cancellation of Flight Agreements - Based on Government Policy}

As a result of the Covid-19 virus pandemic spreading throughout the world, governments in various countries have given instructions to all airlines to continue to prioritize the interests of consumers. The airlines are also advised to notify the delay as early as possible in accordance with applicable procedures, so that passengers' losses can be reduced. Government regulations in various countries instruct airlines to refund fares when flights are canceled. The most common problem is that airlines do not return

\footnotetext{
12 Ministry of Foreign Affairs of the Republic of Indonesia. (March 22, 2020). "Kerjasama Internasional". untuk Percepatan Penanggulangan Covid-19". Retrieved From Kementerian Luar Negeri RI: http://www.kemlu.go.id . Accessed April 14, 2020
} 
flight cancellations in cash, but offer vouchers or travel credit that must be used at the end of the year. Although there are also airlines that return it in cash, in fact, there are some airlines that have extended the voucher validity period to May 2022. The aviation industry approaches the Government to expand regulations and allow travel credit ${ }^{13}$.

Based on current facts, on cancellations made by the passengers, airlines usually charge fees. However, at present, they are freeing the costs of changes and cancellations, at least for the next few months, or in some cases, until the end of the year. Many operators offer upcoming online flight cancellations in return for refunds in the form of travel vouchers. It's a convenient choice for passengers who are interested in airline travel credit or who want to cancel flights that still have operating schedules. However, the important thing to know is that passengers have right to get their cash refund. Some countries have also reaffirmed that airlines must provide refund for canceled flights. Travel vouchers are now permitted if passengers cancel their trip due to travel warnings, policies to stay at home, and other restrictions ${ }^{14}$.

Furthermore, airlines that make flight restrictions or cancellations must provide clear information to prospective passengers and be able to explain information about the mechanism of refund and provide convenience to the process. However, some airlines that limit and cancel flights claim that restricted or canceled flight tickets can still be used by rescheduling the flights at a certain time later, when the permission to return to normal flight activities have been issued. The procedure carried out by the airline is to notify affected passengers via registered email and SMS when purchasing tickets. There are two offers that can be chosen by passengers who have already bought a ticket at the day. The first option is to reschedule tickets with no terms and conditions and at no

13 Turisno, B. E., Suharto, T., \& Juliana, A. (2016). “Tanggung Jawab Maskapai Penerbangan terhadap Kerugian Konsumen Selaku Penumpang Atas Kehilangan dan Kerusakan Barang Bagasi Tercatat (Studi Kasus PT. Lion Mentari Airlines)". Diponegoro Law Review. Retrieved from https://www.neliti.com . Accessed April 20, 2020

14 Kompas. (March 21, 2020). "Ada Virus Corona, Jumlah Penumpang Pesawat Anjlok Hingga 70 Persen". Retrieved From Kompas: Https://www.kompas.com . Accessed April 17, 2020 
additional cost. The second option is the company will return the passengers' money that have already purchased the ticket, and the ticket refund will done through a credit account in the form of a balance worth the funds for the next ticket purchase, which is given a free time of 365 days. Meanwhile, prospective passengers who have booked tickets through the group booking service, travel agents, or other third parties can contact their respective agents for further assistance ${ }^{15}$.

However, many reports said that there are airlines that have not refunded passengers' tickets due to flight cancellations. Instead, the airlines only give them vouchers that can be used for flights at a later time. However, there are other airlines that have given refund cash. Passengers can also submit a refund or reschedule through the application to follow the government's instruction for social distancing. It should be noted that there are several types of ticket status, namely "Refundable","Non-Refundable", "Reschedulable" and "Non-Reschedulable". For accommodation booking tickets, there is a "Free Cancellation" type ${ }^{16}$. With certain terms and conditions, those who have a "Refundable" ticket status can submit a refund. Meanwhile, those who have a "No Refund" ticket status, based on regulations set by the airlines, roll in for help to solve their problems. The surge for refund, flight rescheduling, and hotel tickets occurred since February, due to the impact of the Corona pandemic that cancelled 12 thousand flights in Indonesia ${ }^{17}$.

In other cases, the regular cancellation provisions of the airline still apply. If a prospective passenger orders tickets directly on the airline, then he can reschedule flight time online. However, if using a third-party website service such as a travel agent, he needs to make changes to the itinerary with that company and not the airline. Some

15 Pambayun, D. S. (2020, April 28). “Cara Refund Tiket Batik, Lion dan Wings Air Akibat Pandemi Covid19”. Retrieved From Tirto.id: http://tirto.id . Accessed May 1, 2020

16 Anwar, M. C. (April 20, 2020). "Curhat Penumpang Pesawat: Batal Terbang, Uangpun "Nyangkut"”. Retrieved From CNBC Indonesia: http://www.cnbcindonesia.com .

17 Wareza, M. (2020, April 23). Refund Tiket Pesawat Tak Wajib Cash, Bisa Voucher, Accessed at 26 April 2020. From CNBC Indonesia: http://www.cnbcindonesia.com 
airlines have made good arrangements to ease the situation. However, not all passengers canceled their trips, some have re-ordered for different dates or changed their trip destination $^{18}$. Prospective passengers who must continue to fly, are required to avoid unnecessary air traffic travel and are required to maintain good hygiene practices, but must maintain social distancing with the people around them, regardless of how they travel. Prospective passengers who must continue their flight, are required to avoid unnecessary air travel and are required to maintain good hygiene practices, but must maintain social distancing with the people around them, regardless of how they travel. Prospective passengers are recommended to bring all necessary documentation, including health insurance cards, hand sanitizers, and additional medicines ${ }^{19}$.

\subsection{Force Majeure and Aviation Responsibilities}

The rules that must be obeyed by airlines require them to do flight restrictions and cancellations. As a consequence of the cancellation, the airline must return the funds to passengers who have purchased travel tickets. The refund is the responsibility of the airline for the cancellation, and it can be done both in the form of cash refund or rescheduling, as described above. However, there are contradictions about airline compensation due to this cancellation. Some did not include it in the Force Majeure category, but some others put it in the Force Majuere category for the safety and health reasons of prospective passengers ${ }^{20}$.

In fact, each country has different opinions about the meaning of force majeure and passenger ticket refunds. Several countries in the world insist that airlines are required

18 Kompas. (2020, April 27). "Mudik Dilarang, Cara Refund Tiket Pesawat dari 6 Maskapai Penerbangan”. Retrieved From https://travel.kompas.com . Accessed May 1, 2020

19 Tempo.Co. (March 31, 2020). "virus corona traveloka sibuk layani pembatalan". Retrieved From Tempo.co: https://travel.tempo.co

${ }^{20}$ Antara Kalteng. (January 18, 2020). “Ingin Batalkan Tiket Pesawat Hingga Aturan Pengembalian Dana Tiket”.. Retrieved From Antara Kalteng: https://www.merdeka.com . Accessed April 20, 2020 
to provide refunds for canceled flights. At this time, passengers are allowed to cancel their travel plans because of travel warnings, policies to stay at home, and other restrictions as a result of government policy. This is not included in the Force Majeure, but only circumstances that occur so that travel delays can be made. Therefore, airlines are asked to return funds in cash or reschedule the trip desired by the passenger. However, there are other country regulations stated that flight cancellations that occur due to flight restrictions or cancellations as a result of the outbreak of the Coronavirus, enter Force Majeure. Based on these thoughts and analysis, there are airlines that are exempted from the obligation to provide compensation as stipulated in the government regulations of each country.

The outbreak of Covid-19 and making it the basis for accepting Force Majuere's arguments cannot be accepted as a legal reason, although many link them with policies or decisions of the National or International Government by referring to the contents of its provisions which could hinder aviation activities. Thus, airlines that make flight restrictions or cancellations feel they must be freed from their obligation to provide a number of compensation due to flight cancellations, as stipulated in the government regulations of each country. If Force Majeure could be the reason for the airline's release from the obligation to carry out flight activities as they should, it would certainly cause harm to prospective passengers (consumers). In terms of compensation due to Covid19 conditions, passengers who have purchased an airplane ticket should be able to get a refund within the period specified by the airline, or change flight schedules according to passengers' rights ${ }^{21}$.

In Indonesia, Presidential Decree Number 12 of 2020 concerning "Determination of Non-Natural Disasters Spreading Coronavirus Disease 2019 (Covid-19) as National Disasters", became a debate and polemic. There are those who argue that the Covid-19

\footnotetext{
21 Qur'ani , H., Elnizar, \& Edwin, N. (March 18, 2020). "Masalah Hukum Penundaan Kontrak Akibat Penyebaran Covid-19". Retrieved Hrom Online: https://www.hukumonline.com/berita/baca/lt5e70df2e855cf/masalah-hukum-penundaankontrak-akibat-penyebaran-covid-19/> . Accessed April 30, 2020.
} 
pandemic is Force Majeure, and there are others who argue the opposite. This difference of opinion occurs among people who are unfamiliar with the notion of law, the parties involved in the debt agreement such as creditors and debtors, legal experts, and legal practitioners. ${ }^{22}$ All have their own understanding and analysis, and this brings up big questions that require answers. Does the issuance of the Presidential Decree enable the parties involved in an agreement to secure themselves in an understanding of Force Majeure?

Force Majeure is condition that occurs beyond human capability, such as flood, earthquake, or overmacht condition, so that the loss cannot be avoided. This condition makes the debtor fails to carry out obligations to the creditor because of an event that occurred outside his authority, i.e., an earthquake, landslide, epidemic, riots, war, and so on. France defines Force Majeur as a greater force. Force Majeure clauses are always included as clauses in every agreement made, to anticipate things that might happen in the future and potentially cause conflicts between related parties.

A forced condition can also be interpreted as a certain condition in which a debtor is prevented from being able to carry out his responsibility due to a situation or event that cannot be predicted when an agreement or contract is made. Responsibility for such circumstances or events cannot be borne by the debtor, while he is not in bad intention. The various types of forced conditions are absolute force conditions (absolute onmogelijkheid), a condition in which the debtor is unable to pay his debts to the creditor, because of the earthquake, flash floods, and lava. Meanwhile, relative force conditions (relatieve onmogelijkheid) a situation which still able the debtor to carry out their responsibilities. Regulations related to force majeure clauses in the Civil Code as an agreement or contract are regulated in Article 1244 and Article 1245. Article 1244 states, "If there is any reason for such, the debtor is compensate for costs, damages and interests if he cannot prove, that the non-performance or the late performance of such obligation, is caused by an unforeseen event, for which he is not responsible and he was

\footnotetext{
22 Lisnawaty W. Badu, et, al; 2018. Alienation Changes In Formation Commission Of Indonesian Constitution Of 1945 (Contemplation Towards The Fifth Amendment), Jurnal Pembaharuan Hukum, Vol. 5 (1); 74-82
} 
not acting in bad faith". Articles 1245 states that "The debtor needs not compensate for costs, damages or interests, if a forced condition or an accident prevented him from giving or doing an obligation, or because of such reasons he committed a prohibited act." In these provisions, there are five things that prevent debtors from reimbursing costs, losses, and interest: an unpredictable events (not included in the basic assumptions in making contracts); events where the responsibility is not on the debtor; events that occur which is not the debtor's fault; events that occur which is not due to the mistakes of the parties involved and there is no bad intention from the debtor.

According to the Author, relating to Covid-19 in Indonesia, Presidential Decree Number 12 of 2020 does not necessarily make the parties involved in an agreement, in this case are airlines, can avoid passenger compensation due to flight cancellation. Airlines cannot evade their responsibilities by seeking protection behind the Covid-19 pandemic situation by interpreting it as a Force Majeure situation. The definition and conditions regarding Force Majeure are clearly regulated in the Civil Code, which is hierarchically governed by legislation ${ }^{23}$ above the Presidential Decree. In addition, the Presidential Decree must be examined more carefully, by referring to Article 4 paragraph (1) of the 1945 Constitution ${ }^{24}$ of the Republic of Indonesia concerning the power of the President to hold a government assisted by his representatives. This Presidential Decree does not mention and include elements of Force Majeur in its consideration and states that Covid19 is a non-natural disaster. It does not state that the meanings of Force Majeure are equivalent to Covid-19, only states that it is a non-natural disaster. Based on the argument presented by the author in this article, the airline is obliged to return the ticket funds to passengers in the form and procedures that have been determined, and cannot hide behind Covid-19 with the understanding of a Force Majeure situation.

\footnotetext{
${ }^{23}$ Dian Ekawaty Ismail, et, al. 2019. The Urgency of Gorontalo Traditional Cultural Regulation Expression as a Form of Legal Protection for National Culture, International Conference on Islamic Development Studies: $1-5$

${ }^{24}$ Herdianto H. R. Balo, et, al. 2020. System for Evidence of Corruption Criminal Act in Indonesia. Asian Journal of Education and Social Studies, Vol. 8 (2): 46-55
} 
The Chicago convention of 1944 regulates the economic aspects of civil aviation, sovereignty over airspace, aircraft registration and nationality, SAR, aviation documents and international civil aviation organizations that are used as references for all civil aviation operators in the world. The economic aspects regulated in the Chicago Convention of 1944 in the context of civil aviation and also discuss aspects of liability for losses incurred by airlines as regulated in the Chicago Convention of 1944 and it is used as a guide in Law No.1 of 2009 concerning Aviation .

Related to liability for losses that arise in the case of civil aviation, the linkages between sources of international law with sources of national law. Have a look at source of national law The 1944 Chicago Convention is the reference standard technical aspects of civil aviation but do not completely regulate aspects liability for losses incurred but this is regulated in The 1929 Warsaw Convention relating to Airline Liability Aviation related losses incurred. Look at the source national law, then RI Law No.1 of 2009 on Aviation has regulated the liability related to losses can be seen in Article 141, Article 144, and Article 145 of Company Law refers to the regulated technical aspects of civil aviation operations in the 1944 Chicago Convention based on the Warsaw Convention 1929 Regarding liability for losses.

In Law No. 1 of 2009 concerning Aviation, regulates the responsibility of the carrier or airline, there are 5 (five) responsibilities of the carrier, namely:

1. Liability for passenger losses in the event of death, permanent disability or injuries resulting from an incident of air transportation on board and / or boarding and disembarkation of aircraft (Article 141);

2. Liability for passenger loss, due to lost, destroyed or damaged checked baggage (Article 144);

3. Responsibility to the sender of the cargo, because the cargo was sent (Article 145)

4. Liability for losses due to delay in carrying passengers and luggage (Article 146)

5. The responsibility of the carrier for loss of cabin baggage, unless the passenger can prove that the loss was caused by the act of the carrier or the person employed by him (Article 143). 
The discussion in this article is at point 4, namely regarding the responsibility for compensation regarding this delay as regulated in the Regulation of the Minister of Transportation PM. 89 of 2015 concerning Handling of Flight Delays (Delay Management) at Scheduled Commercial Air Transport Business Entities in Indonesia, in which commercial airlines are obliged to provide compensation for delays due to delays to prospective passengers. Article 3 of this regulation states that the carrier error does not exempt the air carrier from providing compensation to prospective passengers, and in that regulation states the types of delay time, and if it is analyzed and connected to the Covid-19 situation, namely up to the cancellation of flights carried out by airlines, although due to circumstances or situations that make it impossible to fly, the airlines still have to be responsible, because these things and conditions that occur are not conditions that are described as force majeure conditions as in Article 1245 of the Civil Code, because all activities can still be carried out it's just limited, and Covid-19 is not a disaster that cannot be overcome.

\section{Conclusion and Recommendation}

Government policies issued regarding covid-19 make airlines lose money, because they have reduced the number of passengers carried, and require reimbursement for those who do not travel, as well as the cancellation of some planned flights. This happens because the airline is in accordance with the Chicago Convention of 1944 and article 146 Law 1 of 2009 still has to be responsible for the passengers, mail and cargo it carries. To cover this loss, the airline cannot use a force major clause because of this government policy. To assist airlines, the Indonesian government has issued several incentive provisions for airlines such as exemption from tax obligations and certain fees for airlines, etc.

This paper is expected to be input for the Government. As the party that issues the policy, the Government must be able to see a balance in social life and provide appropriate legal protection. ${ }^{25}$ The government should not issue policies that can lead

\footnotetext{
${ }^{25}$ Fenty U. Puluhulawa, et, al. Legal Weak Protection of Personal Data in the 4.0 Industrial Revolution Era, Jambura Law Review, vol. 2 (2): 182-200
} 
to different interpretations from those who read the policies. For Law Academics, it is expected that they can develop and analyze policies issued by the Government by referring to theories and definitions that underlie it, and by referring to the regulations above which support the policy. For Legal Practitioners, with the policies issued by the Government, then in analyzing a case, he must be able to use the right source of law about the definition of Force Majeure. This is necessary, because people need to get a clear understanding relating to this matter.

There are many articles on air transportation written by the other authors. However, air transportation relating to ticket cancellations and the obligation to pay compensation to passengers and force majeure as a justification to avoid compensation has not been met by the author. Thus, the author can state that the idea of this article is a novelty.

\section{Acknowledgement}

For the publication of this paper in the Jambura Law Review Journal, I would like to thank the reviews for reviewing this article, so that the input given greatly adds to my insight as a writer to dig deeper into knowledge. Air transportation sector and finally completes this paper. I would also like to thank the Editor in Chief of the Jambura Law Review Journal, Novendri M. Nggilu who quickly replied via email to me that the writing would be reviewed soon. I also express my thanks to Mellisa Towadi, S.H., M.H, as the Managing Editor of the Jambura Law Review Journal, who was very helpful to the author when asking about the publication of this article. Finally, thank you to Yusrizal, S.H., M.H., Who always encouraged the writer to keep writing.

\section{References}

Antara Kalteng. (January 18, 2020). "Ingin Batalkan Tiket Pesawat Hingga Aturan Pengembalian Dana Tiket".. Retrieved From Antara Kalteng: https://www.merdeka.com . Accessed April 20, 2020

Anwar, M. C. (April 20, 2020). "Curhat Penumpang Pesawat: Batal Terbang, Uangpun "Nyangkut"'. Retrieved From CNBC Indonesia: http://www.cnbcindonesia.com .

Button, K. (2011). "The Economist's Perspective on Regional Endogenous Development". Cheltenham: Regional Endogenous Development. 
Chaeruddin. (March 27, 2020). "Bandara Bua Kurangi Jadwal Penerbangan untuk Cegah Covid-19". Retrieved From Sindo News: http://www.sindonews.com . Accessed April 20, 2020.

CNN Indonesia. (March 18, 2020). "Informasi Pembatalan Penerbangan Terkait Virus Corona, Accessed at 20 April 2020". Retrieved From CNN Indonesia: Https://www.m.cnnindonesia.com

Dian Ekawaty Ismail, et, al. 2019. The Urgency of Gorontalo Traditional Cultural Regulation Expression as a Form of Legal Protection for National Culture, International Conference on Islamic Development Studies: 1-5

Fenty U. Puluhulawa, et, al. Legal Weak Protection of Personal Data in the 4.0 Industrial Revolution Era, Jambura Law Review, vol. 2 (2): 182-200

Herdianto H. R. Balo, et, al. 2020. System for Evidence of Corruption Criminal Act in Indonesia. Asian Journal of Education and Social Studies, Vol. 8 (2): 46-55

Kata Data. (2020). “Cegah Corona Air Asia Setop Semua Penerbangan di Indonesia per 1 April 2020. Retrieved From Http://katadata.co.id . Accessed April 21, 2020

Kompas. (March 21, 2020). "Ada Virus Corona, Jumlah Penumpang Pesawat Anjlok Hingga 70 Persen". Retrieved From Kompas: Https://www.kompas.com . Accessed April 17, 2020

Lisnawaty W. Badu, et, al; 2018. Alienation Changes In Formation Commission Of Indonesian Constitution of 1945 (Contemplation Towards The Fifth Amendment), Jurnal Pembaharuan Hukum, Vol. 5 (1); 74-82

Ministry of Foreign Affairs of the Republic of Indonesia. (March 22, 2020). "Kerjasama Internasional". untuk Percepatan Penanggulangan Covid-19". Retrieved From Kementerian Luar Negeri RI: http://www.kemlu.go.id . Accessed April 14, 2020

Nugraha, B. (2018, 2 20). "Pertumbuhan Sektor Transportasi Udara Cerminkan Ekonomi Nasional". Retrieved from Suara Merdeka: Https://www.suaramerdeka.com

Pambayun, D. S. (2020, April 28). "Cara Refund Tiket Batik, Lion dan Wings Air Akibat Pandemi Covid-19". Retrieved From Tirto.id: http://tirto.id . Accessed May 1, 2020

PT Angkasa Pura. (March 20, 2020). “Sikapi Dampak Pandemi Covid 19, Angkasa Pura Airports Berlakukan Penyesuaian Operasional 15 Bandara". Retrieved from PT. Angkasa Pura: https://ap1.co.id/id/information/news/detail/sikapi-dampakpandemi-covid19-angkasa-pura-airports-berlakukan-penyesuaian-operasional15-bandara . Accessed April 20, 2020. 
Siahaan, D. (February 21, 2018). "Pertumbuhan Sektor Transportasi Udara Mencerminkan Pertumbuhan Ekonomi Nasional". Retrieved from Suara Merdeka Https://www.haloindonesia.co.id

Tempo.Co. (March 31, 2020). "virus corona traveloka sibuk layani pembatalan". Retrieved From Tempo.co: https://travel.tempo.co

Travel Kompas. (2020, April 27). "Mudik Dilarang, Cara Refund Tiket Pesawat dari 6 Maskapai Penerbangan". Retrieved From https://travel.kompas.com . Accessed May 1, 2020

Tusmar, T., \& Mora, M. (2015). "Perkembangan Perekonomian Wilayah dan Kargo Wilayah dan Kargo Udara: Korelasi atau Kausalitas?". Warta Ardhia Jurnal Perhubungan Udara.

Widianto, S. (March 26, 2020). "Pandemi Covid-19, Industri Penerbangan Indonesia Terpuruk, Gelombang PHK Menghantui". Retrieved From Pikiran Rakyat Com: Http://www.pikiranrakyat.com . Accessed April 20, 2020

Wareza, M. (2020, April 23). Refund Tiket Pesawat Tak Wajib Cash, Bisa Voucher, Accessed at 26 April 2020. From CNBC Indonesia: http://www.cnbcindonesia.com

Qur'ani , H., Elnizar, \& Edwin, N. (March 18, 2020). "Masalah Hukum Penundaan Kontrak Akibat Penyebaran Covid-19". Retrieved From Hukum Online: https://www.hukumonline.com/berita/baca/lt5e70df2e855cf/masalahhukum-penundaan-kontrak-akibat-penyebaran-covid-19/> . Accessed April 30, 2020.

\section{Laws}

Chicago Convention of 1944

Indonesian Law No.1 of 2009 on Aviation

Warsaw Convention of 1929 